13.Про затвердження Порядку оформлення матеріалів про адміністративні правопорушення на морському та річковому транспорті : Наказ Міністерства інфраструктури України від 18 квітня 2013 р. (станом на 01 листопада 2019 р.). URL: http://zakon2.rada.gov. ua/laws/show/z0744-13.

14.Про внесення змін до Кодексу України про адміністративні правопорушення щодо підвищення розмірів стягнень за порушення законодавства з безпеки на морському та річковому транспорті : Проект Закону України. URL: http://w1.c1.rada.gov.ua/pls/ zweb2/webproc2 5_1_J? date1=\&date2=\&id=\&name_ zp=\%EA $\%$ EE $\%$ E4\%E5\%EA $\%$ F $1 \% F 3 \&$ num $=\&$ num _s $=2 \&$ out type $=\&$ page $=165 \& z p \_c n t=20$.

БЕРНАДІН В. А., ад’юнкт кафедри публічного управління та адміністрування

(Національна академія внутрішніх справ)

УДК 341.45:342.2:336.222

DOI https://doi.org/10.32842/2078-3736-2019-6-2-2

\title{
ЗАРУБІЖНИЙ ДОСВІД ПРОТИДІЇ ПРАВОПОРУШЕННЯМ У СФЕРІ ОБІГУ ПІДАКЦИЗНИХ ТОВАРІВ
}

У статті проаналізовано зарубіжний досвід правової регламентації суспільних відносин щодо протидії правопорушенням у сфері обігу підакцизних товарів. Запропоновано організаційно-правові заходи 3 метою підвищення ефективності протидії таким правопорушенням. Рекомендовано внести зміни до чинного законодавства для впровадження організаційно-правові моделі фінансової поліції чи служби фінансових розслідувань.

Визначено організаційно-правові моделі подальшого створення фінансової поліції чи служби фінансових розслідувань, аналоги яких можливо зустріти в інших державах, запропоновано розглянути питання створення на базі підрозділів Державної фіскальної служби України, Державної фінансової інспекції України, підрозділів Національної поліції та Служби безпеки України спеціального центрального органу виконавчої влади, який матиме повноваження запобігання та протидії правопорушення у фінансовій сфері й економіці, в т. ч. щодо протидії правопорушенням у сфері обігу підакцизних товарів, і підпорядковуватиметься Міністерству фінансів України.

Визначено, що створення і функціонування фінансової поліції чи служби фінансових розслідувань дозволить: створити єдиний орган, уповноважений на протидію правопорушенням у сфері обігу підакцизних товарів, який буде концентрувати необхідні повноваження. Зазначене усуне дублювання наявних повноважень Національної поліції України, Служби безпеки України та Державної фіскальної служби України щодо протидії правопорушенням у сфері обігу підакцизних товарів. Крім, того, дозволить організувати дієву взаємодію з іншими правоохоронними органами у процесі обміну інформацією, а також забезпечити достатній рівень матеріально-технічного, інформаційно-комунікаційного, соціального забезпечення. Створення такого органу вимагає кропіткої кадрової роботи, що допоможе набрати досвідчених, професійних працівників

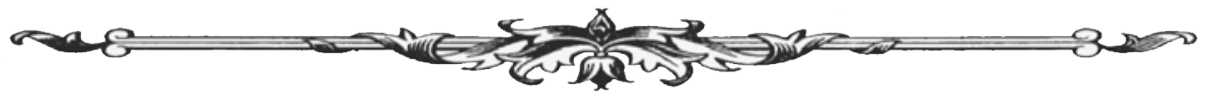


за результатами публічного конкурсу, здатних якісно виконувати свої посадові обов'язки щодо протидії правопорушенням у сфері обігу підакцизних товарів.

Ключові слова: адміністративні правопорушення, підакцизні товари, протидія правопорушенням, служба фінансових розслідувань, фінансова поліичя.

The article analyzes the foreign experience of legal regulation of social relations in counteracting offenses in the area of circulation of excisable goods. Organizational and legal measures are proposed to increase the effectiveness of counteraction to offenses in the field of excisable goods circulation. It is recommended to amend existing legislation for the functioning of the organizational-legal model of financial police or financial intelligence service.

Organizational and legal models of further creation of financial police or financial investigation service, analogues of which can be found in other countries, are defined. But it is proposed to consider the creation on the basis of units of the State Fiscal Service of Ukraine, the State Financial Inspectorate of Ukraine, units of the National Police and Security Service of Ukraine, a special central executive body, which will have the authority to prevent and combat offenses in the financial sector and the economy, including counteraction offense in the field of circulation of excisable goods, which will be subordinated to the Ministry of Finance of Ukraine.

It is determined that the establishment and operation of financial police or financial investigation service will allow: to create a single body authorized to counter offenses in the field of circulation of excisable goods, which will concentrate the necessary powers. The duplication of the existing powers of the National Police of Ukraine, the Security Service of Ukraine and the State Fiscal Service of Ukraine on counteracting offenses in the sphere of circulation of excisable goods is stated. In addition, it will allow to organize effective interaction with other law enforcement agencies in the process of information exchange, as well as to provide a sufficient level of logistical, information and communication, social security. The creation of such a body requires a lot of hard work that will help to recruit experienced, professional employees, according to the results of a public competition, capable of qualitatively fulfilling their official duties in dealing with offenses in the field of circulation of excisable goods.

Key words: administrative offenses, excisable goods, counteraction to the offense, financial investigations, financial police.

Вступ. Важливою складовою частиною національної безпеки є економічна безпека держави, яка відіграє значну роль у забезпеченні економічного зростання населення, підвищення конкурентоспроможності вітчизняної економіки, формування рівних умов для розвитку великого, середнього та малого підприємництва. Сьогодні особливо актуальними $€$ питання, пов'язані з глобалізацією, інформатизацією економіки, забезпеченням невпинного підвищення рівня життя населення, скороченням розриву за рівнем достатку між бідними та багатими, налагодженням конструктивної співпраці з провідними економічно розвиненими країнами, запобіганням відтоку капіталу. Адже наявна фінансово-економічна криза в Україні та значний рівень тіньової економіки стали наслідком трансформації правопорушень у сфері обігу підакцизних товарів. Тому економічна безпека держави перебуває під впливом цілої низки загроз і ризиків, які порушують її стабільність і здатність до саморозвитку та прогресу.

Прояви нелегального обігу підакцизних товарів і їхні масштаби становлять собою форму нелегальної економічної діяльності, яка спрямована на отримання надприбутків шляхом вчинення правопорушень. Тому тільки притягнення до юридичної відповідальності правопорушників і вилучення із незаконного обігу підакцизних товарів $є$ малоефективними.

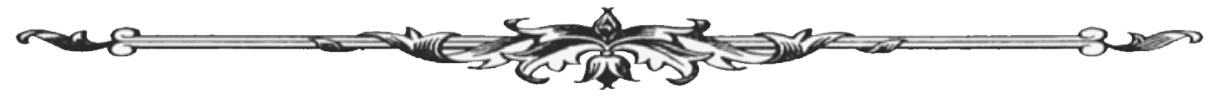


Надто високий рівень рентабельності дозволяє правопорушникам легко переживати втрати, пов'язані з вилученням підакцизних товарів, якими вони оперують. Надвисока прибутковість цієї діяльності зберігає мотивацію правопорушників до протиправної діяльності зважаючи на неможливість настання для них негативних наслідків. Фізична відокремленість лідерів злочинних угрупувань та основних бенефіціаріїв кримінальних оборудок від безпосереднього вчинення правопорушень дозволяє їм уникати відповідальності та робить нелегальний бізнес у сфері обігу підакцизних товарів для них не лише прибутковим, а й безпечним.

У зв'язку з цим доцільним є проведення порівняльно-правового (компаративного) аналізу організаційно-правових заходів протидії правопорушенням у сфер обігу підакцизних товарів для визначення найбільш обгрунтованих, якісних шляхів використання позитивного зарубіжного досвіду у вітчизняному законодавстві з метою підвищення ефективності протидії таким правопорушенням в умовах недостатніх ресурсів. Це зумовлено тим фактором, що в умовах розвитку сектору безпеки й оборони ще досі остаточно не сформовано коло уповноважених суб'єктів щодо протидії правопорушенням у сфері обігу підакцизних товарів.

Питанням визначення адміністративно-правових заходів протидії правопорушенням у сфері обігу підакцизних товарів приділяли увагу такі вчені, як О.М. Бандурка, Ю.В. Гаруст, О.Ю. Дрозд, С.В. Ківалов, В.К. Колпаков, О.В. Кузьменко, С.І. Лепський, Ю.С. Шемшученко, C.А. Шепетько та ін. Наукові здобутки цих фахівців мають науково-прикладне значення для науки адміністративного права, але сучасні потенційні та реальні загрози економічній безпеці України зумовили потребу у розгляді зарубіжного досвіду правової регламентації діяльності суб'єктів, уповноважених протидіяти правопорушенням у сфері обігу підакцизних товарів.

Постановка завдання. Метою статті є визначення зарубіжного досвіду регулювання відносин, що виникають у процесі протидії правопорушенням у сфері обігу підакцизних товарів, а також надання практичних рекомендацій для підвищення ефективності цієї діяльності в Україні.

Результати дослідження. Слід відзначити, що, за результатами аналізу зарубіжного досвіду протидії правопорушенням у сфері обігу підакцизних товарів, нам не варто відразу копіювати організаційно-правові моделі забезпечення боротьби з цими суспільно небезпечними діяннями, а врахувати позитивні та негативні риси. Адже зрозуміло, що в умовах різної правової культури населення, практики застосування законодавства, іншої побудови правоохоронних органів, рівня життя ефективна побудова система суб'єктів по боротьбі 3 правопорушеннями у сфері обігу підакцизних товарів, яка існує в одній країні, не завжди може показати свою надійність у нашій країні. Тому варто з урахуванням зарубіжного досвіду визначити типові варіанти механізму побудови організаційно-правової моделі протидії правопорушенням у сфері обігу підакцизних товарів, а згодом, враховуючи недоліки вітчизняного сектору безпеки, запровадити найбільш позитивні риси зарубіжних країн.

Варто зауважити, що зарубіжний досвід передбачає перший варіант розподілу повноважень у сфері протидії незаконному обігу підакцизних товарів - суто «поліцейський» підхід, коли ці функції інтегровані в діяльність поліцейських органів. Наприклад, у таких країнах, як Данія і Норвегія поліція поєднує функції протидії традиційній злочинності щодо порушення майнових прав, а також порушенням податкового, митного законодавства. Податкові та митні служби в цих країнах не мають повноважень щодо розслідування кримінальних проваджень, а здійснюють тільки адміністрування податків. Словенська модель відрізняється від окресленої тим, що фінансову розвідку віднесено до функцій Міністерства фінансів [1].

Другий варіант утворення і функціонування фінансової поліції характеризується наявністю єдиного воєнізованого правоохоронного органу, до повноважень якого входить боротьба з економічними правопорушеннями. Для прикладу, в Італії є воєнізована правоохоронна структура, яка містить повноваження боротьби з економічними злочинами, в т. ч.

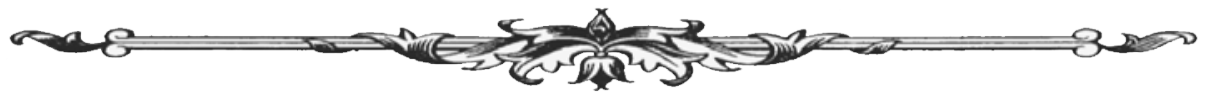


щодо протидії правопорушенням у сфері обігу підакцизних товарів. Зокрема, так само як і у Словенії фінансова гвардія Італії відповідно до законодавства підпорядкована Міністерству економіки і фінансів, а не Міністерству внутрішніх справ. Так, фінансова гвардія в Італії має повноваження щодо попередження та припинення валютних, фінансових і податкових злочинів. Фінансова гвардія входить до складу італійських Збройних Сил, доповнюючи їх і виступаючи військовою структурою [2].

Функціонування єдиного органу фінансової поліції щодо протидії економічним правопорушенням, в т. ч. незаконному обігу підакцизних товарів, притаманне законодавству Республіки Казахстан. Так, Агентство Республіки Казахстан по боротьбі з економічною і корупційною злочинністю (фінансова поліція) є державним органом Республіки Казахстан, безпосередньо підлеглим і підзвітним Президентові Республіки Казахстан. Основними завданнями Агентства $є:$ 1) забезпечення в межах повноважень економічної безпеки держави, законних прав і інтересів суб'єктів підприємницької діяльності, суспільства і держави; 2) попередження, виявлення, припинення, розкриття і розслідування корупційних, економічних і фінансових злочинів і правопорушень; 3) участь у розробці та реалізації державної політики в сфері боротьби з корупцією та злочинністю у сфері економіки; 4) здійснення міжнародного співробітництва з питань, віднесених до відання органів фінансової поліції [3].

У Республіці Білорусь загальне керівництво органами фінансових розслідувань, які уповноважені на протидію правопорушенням у сфері обігу підакцизних товарів, здійснює Президент Республіки Білорусь, а також Голова Комітету державного контролю Республіки Білорусь відповідно до повноважень, покладених на нього законом та іншими законодавчими актами. До системи органів фінансових розслідувань входять: 1) Департамент фінансових розслідувань Комітету державного контролю Республіки Білорусь із правами юридичної особи; 2) управління Департаменту по областям, по Мінській області та м. Мінську з правами юридичної особи; 3) міжрайонні відділи управлінь Департаменту по областям, по Мінській області та м. Мінську. Основними завданнями органів фінансових розслідувань $€: 1)$ захист інтересів суспільства і держави від злочинних та інших протиправних посягань в економічній сфері, забезпечення економічної безпеки Республіки Білорусь; 2) захист прав і законних інтересів громадян Республіки Білорусь, іноземних громадян та осіб без громадянства і організацій в економічній сфері; 3) профілактика, виявлення та припинення злочинів і адміністративних правопорушень в економічній сфері, в т. ч.і корупційних правопорушень; 4) проведення дізнання у кримінальних справах, ведення адміністративного процесу відповідно до їх компетенції [4].

Третій варіант організаційно-правового механізму протидії правопорушенням у сфері обігу підакцизних товарів характеризується об’єднанням податкових і митних служб як правоохоронних органів у рамках однієї адміністративної структури. Таку модель мають Австрія, Велика Британія, Ірландія, Нідерланди, Португалія, Іспанія, а поза межами Свропи Південна Африка. Однак така організація не охоплює всі функції. Злочини, не пов'язані 3 порушеннями податкового і митного законодавства (або у випадках, коли такі правопорушення не є визначальними), належать до компетенції поліції. Крім того, в усіх зазначених країнах, окрім Іспанії та Південної Африки, поліція здійснює і функції фінансової розвідки (в Іспанії і Південній Африці - Міністерство фінансів). У Бельгії та Словаччині також діє інтегрована податкова і митна структура. Однак їі правоохоронні повноваження обмежені митними справами, податкові правопорушення розслідує поліція [1]. Для прикладу, Бюро розслідування фінансових злочинів у Македонії має повноваження досудового розслідування фінансових, податкових і митних правопорушень, в т. ч. у сфері протидії незаконному обігу підакцизних товарів [5].

Четвертий варіант організаційно-правового механізму функціонування уповноважених правоохоронних органів у сфері протидії незаконному обігу підакцизних товарів характеризується різноманіттям суб'єктів, які мають право залучатися до такої діяльності. Так, наприклад, у Люксембурзі, Фінляндії, Франції, Чехії податковими розслідуваннями займається поліція, податкова служба здійснює тільки адміністрування податків і зборів, а

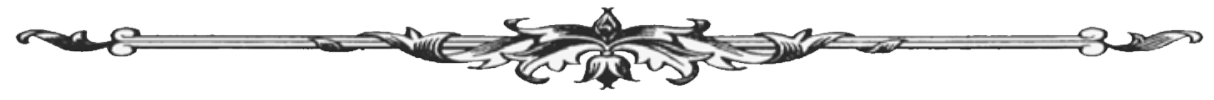


митна служба має власні правоохоронні повноваження. Різниця між цими країнами полягає у тому, що в Люксембурзі та Фінляндії фінансову розвідку віднесено до компетенції поліції, а у Франції та Чехії - Міністерства фінансів. У Німеччині, Швейцарії і Швеції, а поза межами Європи - Нової Зеландії, податкові та митні служби мають власні правоохоронні повноваження, які не перетинаються $з$ функціями поліції, однак поліція здійснює фінансову розвідку. Низка країн поза межами Європи - Австралія, Індія, Канада, Південна Корея, США, Чилі - мають подібну модель, за винятком того, що фінансова розвідка належить до компетенції Міністерства фінансів [1].

У США діяльність правоохоронних органів максимально наближена до фінансової сфери. Так, Міністерство фінансів США (Department of the Treasury) поряд із класичними для фінансових відомств завданнями наділене функціями по боротьбі з фінансовими злочинами, в т. ч. протидії правопорушенням у сфері обігу підакцизних товарів. У структурі Мінфіну США створені Служба внутрішніх доходів (Internal Revenue Service, IRS) 3 мережею підрозділів, що займаються виявленням і розслідуванням фінансових злочинів (IRS Criminal Investigation) [6, с. 191].

Таким чином, за результатами аналізу зарубіжного досвіду протидії правопорушенням у сфері обігу підакцизних товарів можна зазначити, що поєднання в одному органі повноважень щодо запобігання, виявлення та протидії таким правопорушенням можлива у разі підпорядкування такого органу Міністерству внутрішніх справ або Міністерству фінансів. Закріплення в єдиному органі повноважень щодо запобігання, виявлення та припинення правопорушень у сфері обігу підакцизних товарів зустрічається в Італії, Македонії, Білоруciï, Казахстані, однак підпорядковується цей орган Міністерству економіки та фінансів або Президенту.

Таким чином, за результатами аналізу зарубіжного досвіду протидії правопорушенням у сфері обігу підакцизних товарів можна зазначити, що створення і функціонування фінансової поліції дозволить: 1) створити єдиний орган уповноважений на протидію правопорушенням у сфері обігу підакцизних товарів, який концентруватиме необхідні повноваження; 2) усунути дублювання повноважень Національної поліції України, Служби безпеки України та Державної фіскальної служби України щодо протидії правопорушенням у сфері обігу підакцизних товарів; 3) організувати дієву взаємодію з іншими правоохоронними органами у процесі обміну інформацією; 4) забезпечити достатній рівень матеріально-технічного, інформаційно-комунікаційного, соціального забезпечення; 5) за результатами публічного конкурсу набрати досвідчених, професійних працівників здатних якісно виконувати свої посадові обов’язки щодо протидії правопорушенням у сфері обігу підакцизних товарів.

Ми погоджуємося 3 думкою С.А. Шепетька, що, якщо спочатку ставиться питання щодо створення фінансової поліції як суб'єкта забезпечення фінансового контролю, а згодом вирішується проблема врегулювання економічної безпеки держави, то порушується логічний зв’язок між функціями держави й органами як їі окремими елементами. Орган не може утворюватися без чіткого розуміння самої системи економічної безпеки держави, визначення взаємозв'язків між ії елементами та тієї нової якості, яка повинна утворитися у разі функціонування цієї системи загалом. Таким чином, на законодавчому рівні слід спочатку прийняти закон про організаційно-правові основи економічної безпеки України, а згодом утворювати фінансову поліцію [7, с. 286].

Висновки. 3 урахування проведеного аналізу зарубіжного досвіду протидії правопорушенням у сфері обігу підакцизних товарів можна визначити такі організаційно-правові моделі створення фінансової поліції чи служби фінансових розслідувань:

- створення Служби фінансових розслідувань як центрального органу правоохоронного органу виконавчої влади зі спеціальним статусом на базі Державної фіскальної служби України;

- створення фінансової поліції як відокремленого підрозділу Національної поліції, на яку покладатимуться обов'язки 3 виявлення, запобігання, протидії правопорушенням у сфері економіки, в т. ч. незаконного обігу підакцизних товарів;

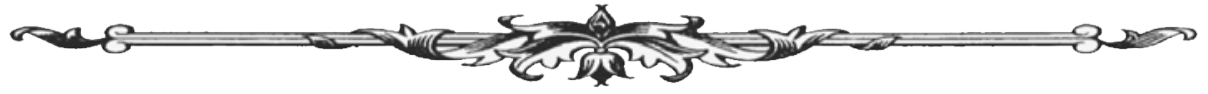


- створення служби фінансових розслідувань України (фінансової поліції) як органу, який буде правонаступником Державної фіскальної служби України, Державної фінансової інспекції України, Департаменту захисту економіки (у складі кримінальної поліції) Національної поліції України, контррозвідувального захисту інтересів держави у сфері економічної безпеки Служби безпеки України та підпорядковуватиметься безпосередньо Президенту України, в окремих випадках Прем'єр-міністру України;

- створення на базі підрозділів Державної фіскальної служби України, Державної фінансової інспекції України, підрозділів Національної поліції та Служби безпеки України, які протидіють злочинам у сфері економіки, спеціального центрального органу виконавчої влади, що матиме повноваження запобігання та протидії правопорушення у фінансовій сфері й економіці, в т. ч. щодо протидії правопорушенням у сфері обігу підакцизних товарів, що підпорядковуватиметься Міністерству фінансів України.

Сьогодні оцінка діяльності правоохоронних органів, в т. ч. реформованої поліції, перебуває на доволі низькому рівні. Крім того, широке коло повноважень, якими буде наділена фінансова поліція, викликатиме певне негативне, упереджене ставлення в осіб, які займаються підприємницькою чи господарською діяльністю у сфері обігу підакцизних товарів, і може породити значні корупційні ризики. Тому одним із основних завдань служби фінансових розслідувань (фінансової поліції) буде отримання достатнього кредиту довіри від населення завдяки публічній, законній, неупередженій, об'єктивній діяльності з метою ефективного захисту порушених конституційних прав і свобод громадян, держави у сфері обігу підакцизних товарів.

Слід зазначити, що тільки ефективність діяльності уповноважених суб'єктів по протидії правопорушенням у сфері обігу підакцизних товарів без незалежного, об'єктивного, справедливого правосуддя не дозволить забезпечити економічну безпеку держави, а також збільшувати обсяг іноземних інвестицій у нашу країну. Розвиток вітчизняного промислового, сільськогосподарського виробництва $є$ можливим тільки у разі залучення великих іноземних інвестицій за реальної можливості інвестора захистити свої порушені права i свободи, в т. ч. вкладений капітал у сферу обігу підакцизних товарів. Тому реформування сектору безпеки доцільно поєднувати з відповідними змінами у судовій гілці владі, аби правоохоронну діяльність і правосуддя здійснювати особи відповідно й у межах закону.

\section{Список використаних джерел:}

1. Свропейський досвід організації системи протидії економічній злочинності. Аналітична записка. URL: http://www.niss.gov.ua/articles/1106/.

2. Guardia di Finanza. URL: http://www.gdf.gov.it/GdF/it/Home/.

3. Положение об Агентстве Республики Казахстан по борьбе с экономической и коррупционной преступностью (финансовой полиции). URL: https://tengrinews.kz/zakon/ prezident_respubliki_kazahstan/natsionalnaya_bezopasnost/id-U050001557_/.

4. Об органах финансовых расследований Комитета государственного контроля Республики Беларусь : Закон Республики Беларусь от 16 июля 2008 г. № 414-3. URL: http://www.pravo.by/document/?guid=3871\&p0= h10800414/.

5. Financial Police Office. URL:http://www.finance.gov.mk/node/813.

6. Лепський C.I. Зарубіжний досвід використання фінансових розслідування у правоохоронній діяльності. Право і суспільство. № 2. 2014. С. 189-194.

7. Шепетько С.А. Організаційно-правові механізми утворення фінансової поліції. Науковий вісник Херсонського державного університету. Серія: Юридичні науки. 2014. Вип. 3. Т. 2. С. 283-286.

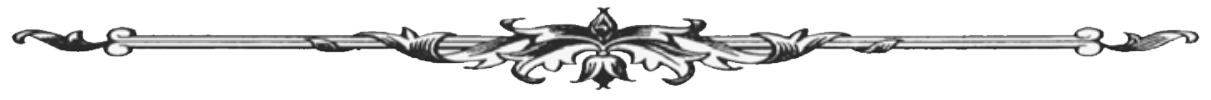

